\title{
Urinary infection in patients of public health care of Campo Mourão-PR, Brazil: bacterial prevalence and sensitivity profile
}

\author{
Infecção urinária em pacientes da saúde pública de Campo Mourão-PR, Brasil: \\ prevalência bacteriana e perfil de sensibilidade
}

Josiane dos Santos Bitencourt ${ }^{1}$; Mariana Felgueira Pavanelli²

\begin{abstract}
Introduction: Cases of bacterial resistance in urinary tract infections (UTIs) have increased significantly, mainly due to indiscriminate use of antimicrobials. Objective: To evaluate the prevalence and antimicrobial susceptibility of microorganisms isolated in urine cultures of patients of Consórcio Intermunicipal de Saúde da Comunidade dos Municípios da Região de Campo Mourão (CISCOMCAM) clinical laboratory. Method: We performed a retrospective study of data from urine culture and sensitivity done between January 2012 and December 2013. Results: The most prevalent bacteria were Escherichia coli; women were the most affected gender and people 16-45 years, the most affected age group. The sensitivity profile showed that the antimicrobial combination trimethoprim/ sulfamethoxazole was not associated with the highest rate of bacterial resistance $(59.7 \%)$ and the combination of amoxicillin/clavulanic acid showed the lowest resistance rate (15.3\%). For most antimicrobials, including ciprofloxacin and norfloxacin, the rates of bacterial resistance have increased from 2012 to 2013 with statistical significance $(\phi<0.05)$ in some cases. Discussion: The prevalence of Gram-negative bacilli in urinary infections is due to the fact that intestinal flora is rich in enterobacteria, and women are most affected by anatomical factors. The development of bacterial resistance to antimicrobials probably arises from their indiscriminate use. Conclusion: The rate of microbial resistance has risen, showing the need for a more effective control of antimicrobial use.
\end{abstract}

Key words: antibiotic susceptibility; bacterial resistance; urine culture.

\section{INTRODUCTION}

Urinary tract infections (UTIs) are the second major cause of community- and hospital-acquired infections ${ }^{(14)}$. UTIs are prevalent in females, especially in the beginning of sexual life and in pregnancy. old people, children up to 1 year old and men with prostatic hyperplasia are also affected by these infections ${ }^{(3,13)}$. Depending on localization of the infection, different names are given to it: urethritis, when it affects the lower urinary tract; cystitis, when it affects the bladder; pyelonephritis, when the bacterium ascends to the kidneys ${ }^{(1,11,13,14)}$.

Microorganisms may reach the urinary tract via the ascending route, the urethra, or the descending route, with bacteria establishing themselves within the kidneys, which may originate from the lymphatic or hematogenous circulation ${ }^{(3,6,13)}$.

The causative agents of UTIs generally belong to the Enterobacteriaceae family; however, the present microorganism and the infection rates may vary according to gender, age group and patient origin ${ }^{(1,12,13)}$. Escherichia coli is one of the most frequently bacteria isolated in patients with UTIs, being responsible for $60 \%-90 \%$ of the community cases, and $50 \%-60 \%$ of the hospital cases. The other community infectious agents are Staphylococcus saprophyticus, mainly in sexually active women; Proteus sp. and Klebsiella sp., in around 10\%-15\% of the cases; and Staphylococcus aureus, responsible for around $3 \%$ of these infections. In hospital-acquired infections, the most frequently isolated bacteria are Escherichia coli, Pseudomonas

First submission on 02/07/14; last submission on 05/08/14; accepted for publication on 30/09/14; published on 20/10/14

1. Pharmacist graduate from Faculdade Integrado de Campo Mourão.

2. Master's degree in Health Sciences from Universidade Estadual de Maringá (UEM); professor of Parasitology and Microbiology at Faculdade Integrado de Campo Mourão. 
aeruginosa, Enterococcus faecalis, Enterobacter and Klebsiella sp., pathogens generally considered opportunists ${ }^{(2,13,14)}$.

UTIs may be asymptomatic or symptomatic. Their most frequent manifestations are dysuria, lumbar and suprapubic pain, frequent urination, chills, fever, cloudy urine, urinary urgency and hematuria $^{(11,12)}$.

Urinalysis is used for laboratory diagnosis, and a urine culture is performed for microbe identification; when the result is positive, an antibiogram is advisable in order to guide pharmacological treatment ${ }^{(13)}$.

The antimicrobials of choice are norfloxacin and ciprofloxacin, members of the quinolone and fluoroquinolone classes, due to their adequate spectrum of activity and excellent urinary excretion, besides the low rate of severe side effects. However, they must not be used by pregnant women and children because of their teratogenic effect, besides being associated with articular diseases; in these cases, amoxicillin is the most indicated antimicrobial ${ }^{(5)}$.

In community-acquired UTIs, cases of bacterial resistance have increased. This evolution may occur due to the indiscriminate and/or inadequate use of antimicrobials with or without prescription and on an empiric basis, demonstrating the importance of the antimicrobial sensitivity test for the choice of the adequate pharmaceutical drug ${ }^{(7,12)}$.

Studies show the resistance profile may vary according to the study location, and depending on the patient, the most prevailing bacteria also vary according to age group, gender and place where the patient acquired the infection. This demonstrates the importance of knowing the most common bacteria that cause UTIs in the region of Comunidade dos Municípios da Região de Campo Mourão (COMCAM) and also their antimicrobial sensitivity profile, to instruct health professionals in the adequate treatment.

\section{OBJECTIVE}

The objective of this work was to assess prevalence and antimicrobial sensitivity profile of the microorganisms isolated in urine cultures of patients seen at the clinical laboratory of Consórcio Intermunicipal de Saúde (CIS) of COMCAM.

\section{METHOD}

This is a retrospective epidemiologic survey about the bacteria that most cause UTIs in outpatients and their antimicrobial sensitivity profile, from January 2012 to December 2013. To this end data were collected at the databank of the clinical laboratory of CIS-COMCAM in the municipality of Campo Mourão, state of Paraná (PR).

The analyzed variables were gender, age, and results from urine culture and antibiogram, to estimate possible infection profiles in the region. The inclusion criteria were tests conducted between January 2012 and December 2013 and positive urine cultures with antibiogram.

In the studied laboratory quantitative urine cultures are carried out using chromogenic agar. The criterion to consider a urine culture positive is a colony count greater than $100,000 \mathrm{UFC} / \mathrm{ml}$ of urine. The antibiogram is conducted by means of the disc-diffusion method, using Muller-Hinton agar. The tested antimicrobials, regardless of the isolated bacterial class, were nitrofurantoin, amikacin, nalidixic acid, trimethoprim/sulfamethoxazole, norfloxacin, amoxicillin/ clavulanic acid, ceftriaxone, cefepime, gentamicin, ofloxacin, ampicillin, cephalothin, cefazolin, ciprofloxacin and tetracycline.

For statistical analysis the chi-squared $\left(\chi^{2}\right)$ test was applied with the use of OpenEpi site.

This work was initially approved by the Human Research Ethics Committee (CEP) of Faculdade Integrado Campo Mourão, under report no. 28702014.7.0000.0092 of the Certificate of Presentation for Ethics Appreciation (CAAE).

\section{RESULTS}

For the conduction of this study 5,609 urine cultures were analyzed, of which 1,057 (18.8\%) were positive. Among the positive cultures, in just 819 (14.6\%) samples bacterial identification was performed. The prevalence of etiologic agents of UTIs for the years 2012 and 2013 are represented in Table $\mathbf{1}$.

Most analyzed exams belonged to female patients (91.2\%). In order to estimate the age group most affected by urinary infections in 2012 and 2013, participants were divided in groups and analyzed as shown in Figure 1.

When comparing the frequencies of urinary infections between 2012 and 2013, a significant decrease in the number of cases in patients aged between 16 and 30 years was observed; an expressive increase of infections in the age groups 46-60 years and individuals older than 76 years was also observed.

Because of the highest frequency of cases, the subjects infected with $E$. coli were analyzed individually as to prevalence by age group (Figure 2).

The antimicrobial sensitivity profile of the bacteria isolated from the study patients was analyzed, and results are displayed in Table 2. 
TABLE 1 - Prevalence and variation of microorganisms isolated from the urine of patients seen at CIS-COMCAM between 2012 and 2013

\begin{tabular}{ccccc}
\hline Bacterium & $2012(\%)$ & $2013(\%)$ & \% of variation & $p$ value \\
\hline Pseudomonas sp. & 4.5 & 9.9 & +127.8 & $0.0022^{* *}$ \\
Enterococcus sp. & 2.2 & 3.4 & +55.5 & 0.221 \\
Escherichia coli & 55.6 & 66.1 & +22.8 & $0.0012^{* *}$ \\
Enterobacter sp. & 2.2 & 0 & -2.2 & $0.0031^{* *}$ \\
Staphylococcus sp. & 12.2 & 8.2 & -20.4 & $0.038^{* *}$ \\
Streptococcus sp. & 15.9 & 9.6 & -37.5 & $0.0048^{* *}$ \\
Proteus sp. & 3.2 & 1.6 & -46.1 & 0.1146 \\
Yersinia sp. & 0.5 & 0.7 & -50 & 0.4858 \\
Klebisiella sp. & 3.7 & 0,2 & $-93,3$ & $0,0004^{* *}$ \\
\hline
\end{tabular}

*Chi-squared test; ** $\mathrm{p}<0.05$.

CIS-COMCAM: Consórcio Intermunicipal de Saúde da região da Comunidade dos Municípios da Região de Campo Mourão.

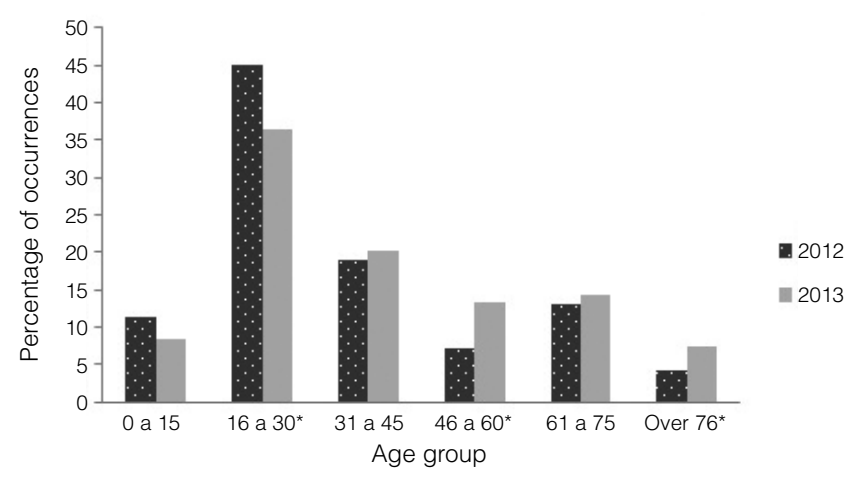

FIGURE 1 -Comparison between age groups of patients seen at CIS-COMCAM from 2012 to 2013

*p $<0.05$ (chi-quared).

CIS-COMCAM: Consórcio Intermunicipal de Saúde da região da Comunidade dos

Municípios da Região de Campo Mourão.

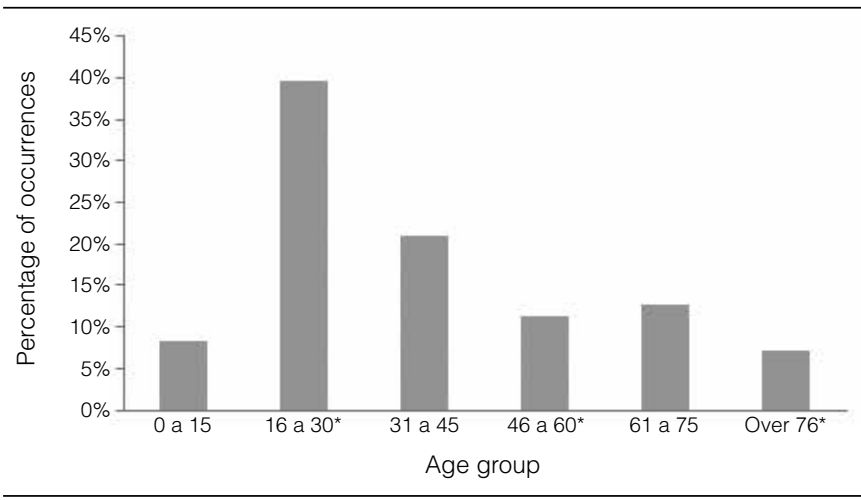

FIGURE 2 -Distribution of infections by Escherichia coli according to the age group of patients seen at CIS-COMCAM

CIS-COMCAM: Consórcio Intermunicipal de Saúde da região da Comunidade dos

Municípios da Região de Campo Mourão.

TABLE 2 - Variation in the antimicrobial resistance profile of bacteria isolated from the urine of patients seen at CIS-COMCAM between 2012 and 2013

\begin{tabular}{ccccc}
\hline Antimicrobial & $2012(\%)$ & $2013(\%)$ & \% of variation & \multicolumn{1}{c}{$p$ value* } \\
\hline Trimethoprim/sulfamethoxazole & 45.8 & 73.7 & +66.4 & $<0.0000001^{* * *}$ \\
Ampicillin & 39.1 & 51.2 & +35.5 & $0.00004^{* *}$ \\
Norfloxacin & 22.2 & 26.4 & +23.5 & 0.0584 \\
Cephalothin & 29.2 & 34.3 & +21.1 & $0.0454^{* *}$ \\
Ofloxacin & 21.1 & 23.6 & +16.5 & 0.1606 \\
Cefazolin & 30 & 33.7 & +16 & 0.1102 \\
Amoxicillin/clavulanic acid & 14.6 & 16 & +13.1 & 0.2925 \\
Ciprofloxacin & 24.6 & 26.1 & +9.4 & 0.3181 \\
Nitrofurantoin & 22.9 & 26.5 & +1.19 & 0.1022 \\
Tetracycline & 50 & 48.3 & - & 0.3252 \\
Naxidilic acid & 66.9 & 60 & -7.47 & $0.0111^{* *}$ \\
Ceftriaxone & 31 & 21.4 & -28.6 & $0.002^{* *}$ \\
Amikacin & 28.6 & 19.8 & -28.8 & $0.0004^{* *}$ \\
Gentamicin & 27.9 & 17.9 & -33.8 & $0.00007^{* *}$ \\
Cefepime & 24.8 & 14.5 & -39.5 & $0.00001^{* *}$ \\
\hline
\end{tabular}

*Chi-squared test; **p $<0.05$.

(-) There was no variation between years.

One may observe there was an increase in microorganism resistance to great part of antimicrobials, including norfloxacin and ciprofloxacin, some of the most currently used drugs in case of UTIs, but this increase was not significant. On the other hand, significant $(p<0.05)$ results were found for cefepime.

For the reason already stated, the variation in the antimicrobial sensitivity profile of $E$. coli was assessed (Table 3). 
TABLE 3 - Variation in the antimicrobial resistance profile of Escherichia coli isolated from the urine of patients seen at CIS-COMCAM between 2012 and 2013

\begin{tabular}{|c|c|c|c|c|}
\hline Antimicrobial & 2012 & 2013 & $\%$ of variation & $p$ value* \\
\hline Trimethoprim/sulfamethoxazole & 39.3 & 66.9 & +109.1 & $<0.0000001$ \\
\hline Ciprofloxacin & 16.1 & 21.4 & +63.9 & 0.0795 \\
\hline Ofloxacin & 15.2 & 19.6 & +58.8 & 0.1190 \\
\hline Cefazolin & 17.8 & 21.4 & +47.5 & 0.1869 \\
\hline Ampicillin & 44.2 & 52.7 & +46.5 & 0.0354 \\
\hline Cephalothin & 26.8 & 28 & +28.3 & 0.4202 \\
\hline Naxidilic acid & 13.8 & 44.4 & +23.2 & 0.4788 \\
\hline Nitrofurantoin & 13.8 & 13.1 & +16.1 & 0.4555 \\
\hline Ceftriaxone & 11.6 & 10.9 & +15.4 & 0.4589 \\
\hline Gentamicin & 12.9 & 11.3 & +6.9 & 0.3324 \\
\hline
\end{tabular}

*Chi-squared test; ** $\mathrm{p}<0.05$.

(-) There was no variation between years.

\section{DISCUSSION}

The present study assessed the prevalence of bacteria that cause UTIs in non-hospitalized individuals in the region of Campo Mourão and their sensitivity profile to the most used antimicrobials. Several studies have already been conducted in the region, however, the study population was most of the times inpatients, different from the patient profile examined in this work $^{(16)}$. As in hospital-acquired infections, differently from the community ones, the most affected age group is that over 60 years, the most frequent bacteria are non-fermenting enterobacteria, and the route of infection is hematogenous or devices, like probes, for example ${ }^{(17)}$.

The etiologic agent most frequently isolated in the urine samples was Escherichia coli (61\%), confirming the results of several authors ${ }^{(3,6,13)}$. Concerning the other urinary pathogens, Braoios $e t ~ a l .{ }^{(3)}$, when analyzing samples of outpatients, found results similar to these in our study. Predominance of infections by gram-negative bacilli is noted. They occur because the intestinal flora is rich in enterobacteria and this region is close to the urethra, the main entry point for urinary pathogens. These findings confirm other works ${ }^{(3,9,10)}$.

Females were more affected (91.2\%), agreeing with the results of other studies, possibly due to anatomical factors, as the ureter is shorter in women than in men and is located closer to the anal area, thus being more susceptible to infections ${ }^{(3,6,13,17)}$.
The most affected age group was 16-45 years (60.3\%), both for total cases and for the isolated analysis of infection by $E$. coli. Hence, in this study, the profile of the infected subjects comprises young women, corroborating previous results ${ }^{(3,6)}$. This happens because women in this age group are normally sexually active, being more susceptible to the main uropathogens that cause

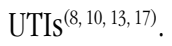

In some places of the world, including Brazil, there are bacteria resistant to all antimicrobials. Nevertheless, some studies show that the intake of antimicrobials, and consequently resistance to them, have decreased because health authorities have controlled the use of these medications ${ }^{(4)}$. Many of these studies did not analyze data using statistical tools, what does not reveal the actual variation in indices of microbial resistance. In the present work, variables of 2012 were compared to those of 2013 , using the $\chi^{2}$ test.

The antimicrobial sensitivity profile of isolated bacteria show that nalidixic acid, trimethoprim/sulfamethoxazole, tetracycline and ampicillin presented the highest rates of bacterial resistance, confirming other authors ${ }^{(3)}$. One may note, though, that in relation to nalidixic acid, resistance by bacteria decreased $7.47 \%$ from one year to the next, contrary to ampicillin (+ 35.5\%) and trimethoprim/sulfamethoxazole $(+66.4 \%)$, which rose significantly $(\phi<0.05)$ from 2012 to 2013.

The rate of bacterial resistance to the quinolone class, most commonly used to treat UTIs, was $24 \%$, but this value was not significant $(\phi>0.05)$. In the study by Braoios et al. ${ }^{(3)}$, the rate 
ranged from $13 \%$ to $14 \%$, that is, from 2009 to 2013 there was an increase in bacterial resistance to this class of medicine. This fact had been foreseen by the respective authors if the use of these antimicrobials continued to occur empirically in an inadequate manner. The same can be observed with the antimicrobial trimethoprim/sulfamethoxazole, which, in this study, had the highest rate of bacterial resistance (59.7\%), a rate that increased significantly $(\not<0.05)$ from 2012 to 2013. Similar results were obtained in a study conducted with women older than 18 years, but with a slightly lower rate, around $40.8 \%{ }^{(11)}$.

The empirical treatment (medical prescription with no antibiogram) must only occur when bacterial resistance to the antimicrobial is lower than $20 \%$, so, if the criterion of this study were used, several antimicrobials should not be empirically prescribed, including quinolones. However, if used, the physician should monitor the patient to analyze if there was improvement ${ }^{(3,13)}$. The pharmacist can help the physician as to the most adequate medicine for each bacterium, revise the prescription so that it is adequate to treatment and advise the patient on the correct form of utilization, storage and importance of adherence to treatment.

The association of amoxicillin with clavulanic acid had the lowest rate of bacterial resistance (15.3\%), increasing from one year to the next (13.1\%) with no significance. Therefore, this drug may be an efficient alternative in UTI treatment for community patients. At a survey conducted in São Luís-MA, with inpatients, from 2005 to 2008, the result was opposite to the ones reached in the present study, in which association of amoxicillin with clavulanic acid for $E$. coli presented a resistance rate of around $40 \%{ }^{(15)}$.

From 2012 to 2013 the microorganism E. coli became more resistant to the following antimicrobials: trimethoprim/ sulfamethoxazole, ampicillin, cefazolin, ciprofloxacin, norfloxacin and ofloxacin; and more sensitive for the treatment with amikacin and cefepime. The resistance of $E$. coli to quinolones was already reported $^{(2)}$. This is worrying, for this bacterial manifestation may affect antibiotic therapy in cases of emergency. The increased bacterial sensitivity to cefepime is extremely important because this drug is used in hospitals and may be used to treat severe infections.

\section{CONCLUSION}

One may conclude that Escherichia coli is the bacterium most commonly identified in UTIs. Females were more affected, as well as people aged $16-45$ years, consequently, sexually active young women. The sensitivity profile shows that for the majority of antimicrobials, the resistance rate increased, with statistical significance $(p<0.05)$ in some cases. Thus, if control upon these drugs is not effective in all environments they are used, bacterial resistance will tend to increase, and in the future some antimicrobials will have no efficacy against some microorganisms.

\section{RESUMO}

Introdução: Os casos de resistência bacteriana nas infecções do trato urinário (ITUs) vêm aumentando significativamente, principalmente devido ao uso indiscriminado de antimicrobianos. Objetivo: Avaliar a prevalência e o perfil de sensibilidade aos antimicrobianos dos microrganismos isolados nas uroculturas de pacientes atendidos no Laboratório de Análises Clínicas Consórcio Intermunicipal de Saúde da Comunidade dos Municípios da Região de Campo Mourão (CIS-COMCAM). Método: Fezse uma pesquisa retrospectiva de dados de urocultura e antibiograma realizados entre janeiro de 2012 e dezembro de 2013. Resultados: A bactéria mais prevalente foi Escherichia coli; o gênero mais acometido foi o feminino; e a faixa etária, de 16 a 45 anos. Operfil de sensibilidade mostrou que o sulfazotrim éo antimicrobiano com a maior taxa de resistência bacteriana (59,7\%), e a associação amoxicilina/ácido clavulânico obteve a menor taxa de resistência (15,3\%). Para a maioria dos antimicrobianos testados, inclusive norfloxacino e ciprofloxacino, a taxa de resistência bacteriana elevou-se de 2012 para 2013, com significância estatística (p <0,05) em alguns casos. Discussão: O predomínio de bacilos Gram-negativos nas infecções urinárias deve-se à flora intestinal, por ela ser rica em enterobactérias. As mulheres são mais acometidas devido aos fatores anatômicos. $O$ desenvolvimento de resistência bacteriana a antimicrobianos provavelmente surge do uso indiscriminado deles. Conclusão: A taxa de resistência microbiana tem-se elevado, mostrando que há necessidade de um controle mais efetivo do uso de antimicrobianos.

Unitermos: antibiograma; resistência bacteriana; urocultura. 


\section{REFERENCES}

1. BARBERINO, M. G. A. Prevalência da resistência a antimicrobianos e uso de testes rápidos no diagnóstico de infecções do trato urinário adquiridas na comunidade. 2010. 100f. Dissertação (Mestrado em Biotecnologia em Saúde e Medicina Investigativa) - Fundação Oswaldo Cruz, Centro de Pesquisas Gonçalo Moniz, Salvador, 2010.

2. BLATT, J. M.; MIRANDA, M. C. Perfil dos micro-organismos causadores de infecções do trato urinário em pacientes internados. Rev Panam Infectol, São Paulo, v. 7, n. 4, p. 10-14, 2005.

3. BRAOIOS, A. et al. Infecções do trato urinário em pacientes não hospitalizados: etiologia e padrão de resistência aos antimicrobianos. J Bras Patol Med Lab, Rio de Janeiro, v. 45, n. 6, p. 449-56, 2009.

4. BRITO, M. A.; CORDEIRO, B. C. Necessidade de novos antibióticos. J Bras Patol Med Lab, Rio de Janeiro, v. 48, n. 4, p. 247-9, 2012.

5. CARVALHO, F. J. W.; ZERINGOTA, R. G. Tratamento da infecção não complicada do trato urinário. Rev Bras Clín Ter, v. 31, n. 2, p. 52-6, 2005.

6. CHAMBÔ FILHO, A. et al. Estudo do perfil de resistência antimicrobiana das infecções urinárias em mulheres atendidas em hospital terciário. Rev Bras Clín Med, São Paulo, v. 11, n. 2, p. 102-7, 2013.

7. GRILLO, V. T. R. S. Incidência bacteriana e perfil de resistência a antimicrobianos em pacientes pediátricos de um hospital público de Rondônia, Brasil. Rev Ciênc Farm Básica Apl, Rondônia, v. 34, n. 1, p. 117-23, 2013.

8. KORB, A. et al. Perfil de resistência da bactéria Escherichia coli em infecções do trato urinário em pacientes ambulatoriais. Rev Biol Ciênc Terra, Paraíba, v. 13, n. 1, p. 72-9, 2013.

9. KOCH, R. C. et al. Resistência antimicrobiana dos uropatógenos em pacientes ambulatoriais, 2000-2004. Rev Soc Bras Med Trop, v. 41, n. 3, p. 277-81, 2008.
10. MACHADO, L. D. P. N. Estudo da Prevalência de uropatógenos e perfil de sensibilidade aos antimicrobianos nos serviços de pronto atendimento da universidade regional de Blumenau. 2010. $41 \mathrm{f}$. Monografia (Graduação em Farmácia) - Universidade Regional de Blumenau, Blumenau, 2010.

11. MAGALHÃES, V. F. et al. Etiologia e perfil de resistência das bactérias isoladas a partir de uroculturas oriundas de mulheres acima de 18 anos. RBM Rev Bras Med, v. 66, n. 2, p. 11-6, 2009.

12. PIRES, M. C. A. et al. Prevalência e suscetibilidades bacterianas das infecções comunitárias do trato urinário, em Hospital Universitário de Brasília, no período de 2001 a 2005. Rev Soc Bras Med Trop, Brasília, v. 40, n. 6, p. 643-7, 2007.

13. RODRIGUES, F. J. B.; BARROSO, A. P. D. Etiologia e sensibilidade bacteriana em infecções do trato urinário. Rev Port Saúde Pública, Espanha, v. 29, n. 2, p. 123-31, 2011.

14. RORIZ FILHO, J. S. et al. Infecção do trato urinário. In: SIMPÓSIO, Condutas em enfermaria de clínica médica de hospital de média complexidade, Ribeirão Preto. Ribeirão Preto, v. 4, n. 2, p. 118-25, 2010.

15. SANTANA, T. C. F. S. et al. Prevalência e resistência bacteriana aos agentes antimicrobianos de primeira escolha nas infecções do trato urinário no município de São Luís. Rev Patol Trop, Goiás, v. 41, n. 4, p. 409-18, 2012.

16. SANTOS, T. K. P. et al. Identificação e perfil antimicrobiano de bactérias isoladas de urina de gestantes atendidas na Irmandade da Santa Casa de Misericórdia de Prudentópolis, Paraná. Semina Cienc Biol Saúde, Londrina, v. 33, n. 2, p. 181-92, 2012.

17. SILVA, J. C. et al. Estudo retrospectivo de bactérias gram-negativas isoladas a partir de uroculturas e determinação de seu perfil de resistência. News Lab, São Paulo, n. 122, p. 82-90, 2014. 